\title{
Non-malignant asbestos pleural disease
}

\author{
GUNNAR HILLERDAL
}

From the Department of Pulmonary Medicine, University Hospital, Uppsala, Sweden

ABSTRACT During a 10-year period (1970-79) all patients in Uppsala County found to have pleural changes related to asbestos exposure were followed. The lesions could be divided into four types: parietal pleural plaques, exudative pleurisy, thickening of the visceral pleura, and progressive pleural fibrosis. There were 891 cases. The most common type was parietal plaques, which was seen in 827 patients, some of whom later developed other changes. In 22 patients exudation was proven radiologically, and in 84 more cases obliteration of the costo-phrenic angle was seen. The exudations almost all had a benign course, despite sometimes fairly large and bloody effusions. They were practically all symptom-free, being a surprise finding on chest radiography. Thickening of the visceral pleura can only be seen radiologically in the fissures and occurred in a few cases in addition to other changes. In a small group of more heavily exposed individuals, a progressive pleural fibrosis developed, sometimes after an initial effusion.

Pleural changes are common among those exposed to asbestos. Most common are plaques on the parietal pleura, which can produce radiographic changes virtually pathognomonic of exposure to asbestos. Unspecific abnormalities, such as exudation and pleural thickening, can also occur. Diagnosis of these changes depends upon a history of asbestos exposure and exclusion of other causes. ${ }^{1}$ A study of asbestos-related pleural changes has been in progress in the county of Uppsala for a 10-year period (1970-79).

\section{Methods}

The county of Uppsala is situated just north of Stockholm. There are approximately 250000 inhabitants, almost half of whom live in Uppsala, a University town with comparatively few industries. There are no dock yards, asbestos factories, or similar former heavy users of asbestos in the county. Persons with asbestos exposure are mainly builders, plumbers, and so on or have worked in small scale manufacturing shops.

A general health survey has been in practice in the county since 1960 . This includes a $100 \times 100 \mathrm{~mm}$ size chest radiograph. All inhabitants from age 15 years and above are invited to participate every second or third year, and the average attendance

Address for reprint requests: Dr G Hillerdal, Department of Pulmonary Medicine, University Hospital, 75014 Uppsala, Sweden. is $70 \%{ }^{2}$ Thus, for many of the inhabitants serial films over a 20-year period are available.

Since 1970, all residents in the county found to have pleural changes thought to be caused by asbestos have been followed. Most have been found in the health survey, but some cases (less than $5 \%$ ) have also been referred to the clinic.

The pleural changes were divided into four types on the basis of radiology (table 1), but two or more types often occurred together in the same patient. The diagnostic criteria were as follows: Pleural plaques were diagnosed only if they were bilateral and of at least grade II according to ILO/ UICC - that is, at least $5 \mathrm{~mm}$ thick when seen tangentially. ${ }^{3}$ Asbestos exposure was not a prerequisite. since exposure can be very difficult to ascertain. Pleural effusions alone were not included unless plaques were present before or developed after the effusion appeared. For such cases significant asbestos exposure was required, and other causes of the effusion had to have been excluded. Only clinically motivated investigations were performed. Thickening of the visceral pleura can only be seen radiologically in the fissures and was diagnosed only in connection with other changes. Progressive pleural fibrosis was thought to be caused by asbestos if there was a history of such exposure and other causes had been excluded. Exposure to asbestos was graded from 1 to 3 on the basis of the patient's history. Grade 1 was intermittent, not very heavy exposure, grade 3 heavy daily use, and grade 2 in between. 
Table 1 Non-malignant asbestos-related pleural changes: classification

\begin{tabular}{|c|c|c|c|c|}
\hline & Afflicted pleura & Appearance & Development & Typical X-ray \\
\hline Parietal pleural plaques & Parietal & Very gradual & $\begin{array}{l}\text { Slowly progressive, } \\
\text { finally calcifies }\end{array}$ & $\begin{array}{l}\text { Clear angles, } \\
\text { apices not affected }\end{array}$ \\
\hline $\begin{array}{l}\text { Uncomplicated pleural } \\
\text { exudate }\end{array}$ & Both & Sudden & $\begin{array}{l}\text { a/disappears without trace } \\
\text { b/leaves obliteration of } \\
\text { costophrenic angle }\end{array}$ & \\
\hline $\begin{array}{l}\text { Thickening of visceral } \\
\text { pleura }\end{array}$ & Visceral & Very gradual & Slowly progressive, can calcify & $\begin{array}{l}\text { Seen only in fissures, mainly in } \\
\text { minor fissure }\end{array}$ \\
\hline $\begin{array}{l}\text { Progressive pleural } \\
\text { fibrosis }\end{array}$ & Both & Can start suddenly & $\begin{array}{l}\text { Can develop over some years } \\
\text { to extensive fibrosis; slow } \\
\text { development also can occur }\end{array}$ & $\begin{array}{l}\text { Sinuses always involved } \\
\text { "Crow's feet" common early } \\
\text { sign. Apices sometimes affected }\end{array}$ \\
\hline
\end{tabular}

\section{Results}

There was a total of 891 persons with pleural changes associated with exposure to asbestos.

\section{Parietal pleural plaques}

These were by far the most common, 827 patients showing such changes some time during the observation period, some of them later developing other types as well. The incidence of new cases was growing each year, and it could be estimated that at the end of 1979 , at least $2.2 \%$ of the men 40 years of age or older had radiological pleural plaques. The plaques were vary rare in women and below age $\mathbf{4 0}$ years.

More than $90 \%$ were asked about exposure to asbestos, and of those, $80 \%$ confirmed exposure. In another $10 \%$, exposure was probable from the occupation. The average time from first exposure to first radiograph fulfilling the criteria was 30 years. The plaques showed a slow and gradual development and could often be suspected on earlier films. They have been thoroughly described in an earlier paper. ${ }^{4}$

The "average grade of exposure" for pleural plaques only was $1 \cdot 4$, if those denying exposure were excluded.

\section{Uncomplicated pleural effusion (figs 1,2)}

Effusion, proven radiologically and in most cases also by aspiration, was found in 22 patients. In four of these the effusion developed into progressive pleural fibrosis (table 2). The exudate tended to persist for some months or up to a year, and sometimes recurred on the same or the other side after one or two years. The fluid was often macroscopically bloodstained and microscopically there was a predominance of erythrocytes or mature lymphocytes or both. Up to three aspirations were performed with 50 to $1500 \mathrm{ml}$ removed (table 3).

As seen in table 2, pleural plaques were present before the effusion or developed afterwards. It is

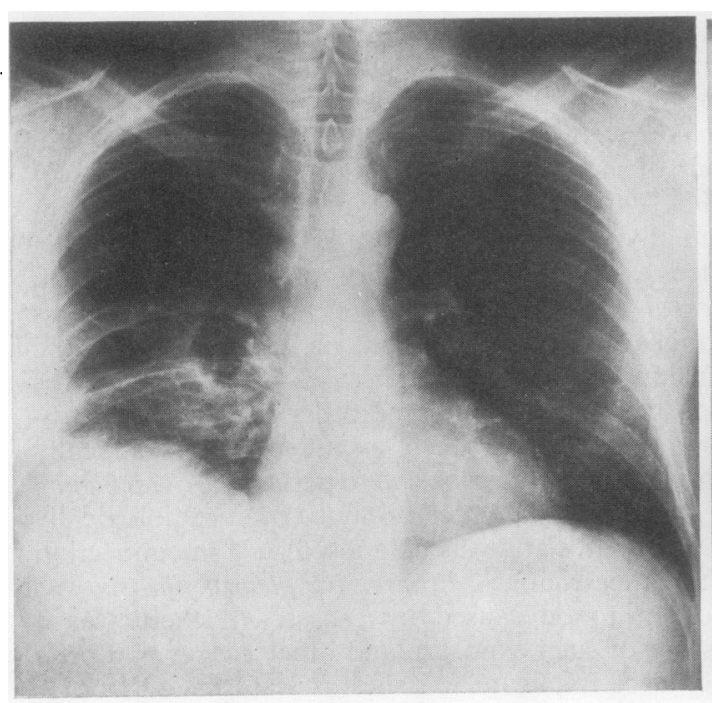

(a)

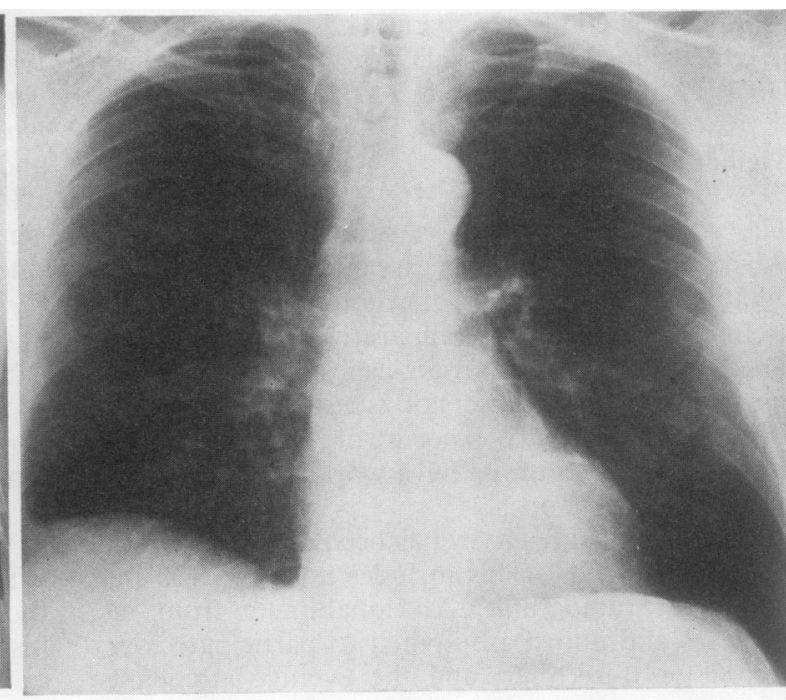

(b)

Fig 1 a: 1972. Right-sided effusion, haemorrhagic at aspiration. No plaques seen. b: 1979, same patient. Rounded angle right, typical plaques left. 


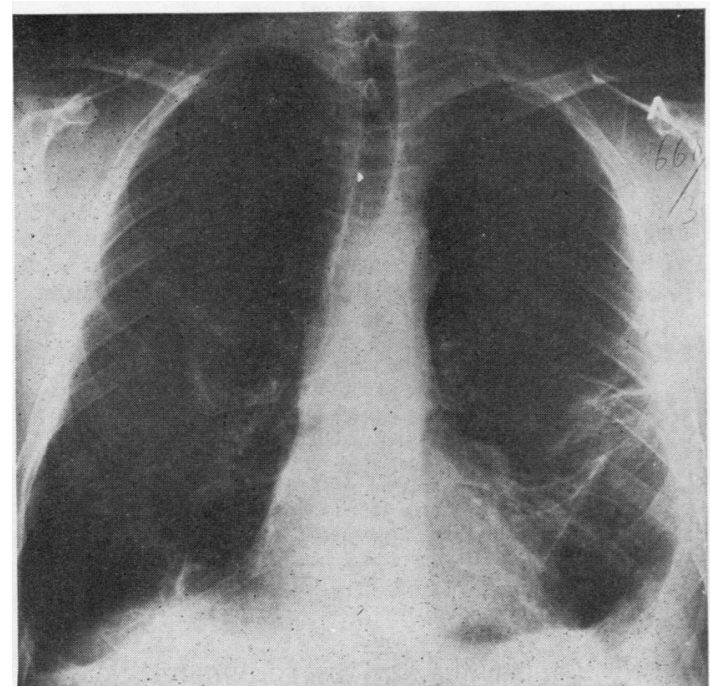

(a)

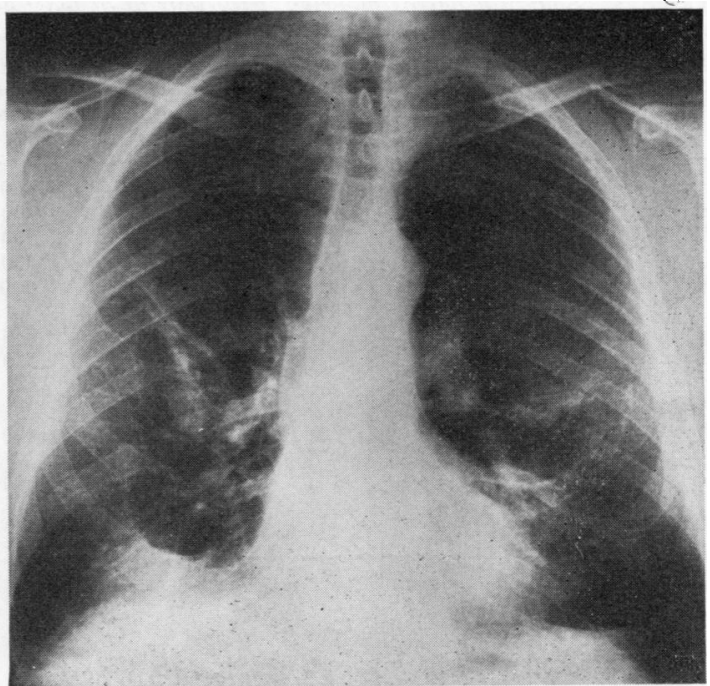

(b)

Fig 2 a: 1973. Small pleural reaction right, exudate left and small "crow's feet". b: 1978, same patient. More extensive changes right. Left, exudate resorbed, probable plaques laterally, remnants of pleurisy.

Table 2 Pleural effusion in 22 cases

\begin{tabular}{|c|c|c|}
\hline Course & $\begin{array}{l}\text { Number of } \\
\text { cases }\end{array}$ & Special notes \\
\hline $\begin{array}{l}\text { Disappeared without trace: } \\
\text { years later pleural plaques }\end{array}$ & 4 & $\begin{array}{l}\text { Persisted } 2-5 \text { months. } \\
\text { Recurrence same side } \\
2 \text { years later in one case }\end{array}$ \\
\hline $\begin{array}{l}\text { Effusion in persons with } \\
\text { pleural plaques; } \\
\text { disappeared without trace }\end{array}$ & 10 & $\begin{array}{l}\text { Persisted up to } 6 \\
\text { months. Two recurrences } \\
2 \text { years later-one same } \\
\text { side, one opposite }\end{array}$ \\
\hline $\begin{array}{l}\text { Left rounded angle; years } \\
\text { later pleural plaques on } \\
\text { opposite side }\end{array}$ & 2 & $\begin{array}{l}\text { Persisted } 2 \text { and } 4 \\
\text { months respectively }\end{array}$ \\
\hline $\begin{array}{l}\text { Effusion in persons with } \\
\text { pleural plaques, leaving } \\
\text { rounded sinus }\end{array}$ & 2 & Persisted 4 months \\
\hline $\begin{array}{l}\text { Developed into progressive } \\
\text { pleural fibrosis }\end{array}$ & 4 & \\
\hline
\end{tabular}

probable that in some cases plaques developed later but were obscured by the remnants of the pleurisy. The plaques seemed in no way affected by the effusion, except for being hidden in the fluid and reappearing when it was resolved or in some cases remaining obscured by pleural thickening afterwards.

Sedimentation rate was usually normal but in a few cases raised to up to $50 \mathrm{~mm}$. Slight leucocytosis was seen only occasionally. There were no signs of collagen diseases. Cytology of the fluid and biopsy of the pleura sometimes gave reason to suspect a tumour but all patients have been followed for at least three years with no signs of neoplasm (table 3).
Typically, there were no or very slight symptoms. Only one patient had a chest film because of symptoms (general malaise and slight pain in the side). All the others were found accidentally and admitted only vague symptoms on questioning. Average grade of exposure was $1 \cdot 3$, and the mean "latency time" around 30 years, with a wide variation of nine to 46 years.

Obliteration of a costophrenic angle with or without some degree of pleural thickening without a known episode of pleural exudate was observed in 84 cases. In 28 cases, it occurred before development of pleural plaques. Depending on the degree of residual pleural thickening, the plaques were seen on the contralateral side only (15 cases) or on both sides (13 cases). In 31 cases sudden obliteration of the angle was noticed on follow-up of pleural plaques. In only five cases was the obliteration accompanied by a considerable thickening of the pleura, but in all five this was still unchanged some years later. Twenty-five patients had bilateral costophrenic angle obliteration.

Average "latency time" was 34 years. Very few patients had noticed any symptoms since the earlier film with a normal angle. The average grade of exposure to asbestos in patients with one or both angles obliterated was $1 \cdot 4$.

\section{Thickening of the visceral pleura (fig 3)}

This was not very common and tended to occur with comparatively heavy exposure, but was not systematically looked for until the last few years. 
Table 3 Benign asbestos pleurisy. Effusions of at least $400 \mathrm{ml}$ at thoracocentesis. Some clinical data

\begin{tabular}{|c|c|c|c|c|c|c|c|c|}
\hline Side & Pre-effusion $X$-roy & $\begin{array}{l}\text { Years from } \\
\text { first exposure }\end{array}$ & $\begin{array}{l}\text { Grade of } \\
\text { asbestos } \\
\text { exposure }\end{array}$ & $\begin{array}{l}\text { Total } \\
\text { amount } \\
\text { tapped } \\
(\mathrm{ml})\end{array}$ & $\begin{array}{l}\text { Times } \\
\text { tapped }\end{array}$ & $\begin{array}{l}\text { Macro- } \\
\text { scopic } \\
\text { appearance }\end{array}$ & $\begin{array}{l}\text { Remnants on } \\
X \text {-ray }\end{array}$ & $\begin{array}{l}\text { Observation } \\
\text { since exudate } \\
\text { (years) }\end{array}$ \\
\hline $\mathbf{R}$ & Plaques & 45 & 1 & 450 & 1 & Bloody & No trace & 3 \\
\hline $\mathbf{R}$ & का & 51 & 2 & 500 & 1 & , & , & 3 \\
\hline $\mathbf{L}$ & $"$ & 22 & 1 & 500 & 2 & $"$ & $"$ & 5 \\
\hline $\bar{L}$ & Normal & 50 & 1 & 600 & 2 & $"$ & Bilateral & 6) \\
\hline$\vec{R}$ & " & 51 & & 300 & 1 & $"$ & $\begin{array}{l}\text { progressive } \\
\text { fibrosis }\end{array}$ & $5\}$ Same patient \\
\hline $\mathbf{L}$ & Plaques & 18 & 1 & 850 & 3 & ", & No trace & 6 \\
\hline $\mathbf{R}$ & Normal & 30 & 2 & 550 & 1 & $"$ & $\begin{array}{l}\text { Obliterated sinus } \\
\text { Plaques other } \\
\text { side } 3 \text { years later }\end{array}$ & 7 \\
\hline $\mathbf{R}$ & Plaques & 17 & 1 & 1000 & 1 & " & $\begin{array}{l}\text { Obliterated } \\
\text { sinus }\end{array}$ & 8 \\
\hline $\mathbf{R}$ & Normal & 33 & 3 & 2000 & 3 & Yellowish & $\begin{array}{l}\text { No trace, } \\
\text { three years } \\
\text { later plaques }\end{array}$ & 18 \\
\hline
\end{tabular}

*See text.

Progressive pleural thickening (fig 3)

This occurred in 27 patients. The costophrenic angles were involved in all. In four it started with an effusion, as mentioned above. The typical finding was progression when observed over a few years. The speed of progression varied. The lesion was always bilateral, even if it often started unilaterally. The first signs were often streaks radiating towards or away from the periphery ("Crow's feet" as described by Mackenzie ${ }^{5}$ ). These probably represent local scarring or convolution of the pleura, and they were also sometimes seen as a non-progressive remnant of pleural effusion. As the disease advanced, these changes became confluent. Unlike all other types, considerable thickening of the pleural cap was sometimes noted.

For various reasons, pleurectomy was performed on one or both sides of four patients. In only one of them was there subjective improvement in dyspnoea. This lack of improvement was caused by coexistent pulmonary fibrosis, proven by pulmonary biopsy.

Sixteen patients started with pleural plaques as the sole abnormality, then developed first unilateral and later bilateral obliteration of the sinuses, and finally extensive thickening of the pleura.

In four cases, calcified plaques were observed through the pleural fibrosis. In three of these, the calcification occurred after the hyaline plaques had been obscured by the fibrosis, indicating that the plaques continue their development independently of other pleural changes.

The latency time was 34 years, and the average exposure to asbestos was $2 \cdot 0$, higher than in the other groups.

\section{Pseudotumour formation}

In six patients, three after effusion and three with progressive thickening, a "pseudotumour" developed-that is, a lesion which on radiography was strongly suggestive of tumour but at operation proved to be visceral pleural thickening and "folded lung".

\section{Discussion}

Pleural changes are common in pulmonary asbestosis. In advanced cases they are mainly progressive thickening, as described here. ${ }^{6}$ The explosive increase in the use of asbestos during and after world war 2 led to a large number of persons being exposed in fairly low doses. With a latency time of three decades, the result of this is now seen and will be seen increasingly in the near future.

At least $2.2 \%$ of men in Uppsala County above age 40 years have radiologically visible pleural plaques and many more at necropsy ${ }^{7}$ and the figure is rising. In areas with dockyards, asbestos factories, and so on the figure will be much higher, and other pleural changes caused by asbestos should also be more common than with the relatively low grade of exposure in Uppsala County.

Pleural effusion is a well-known sequel to asbestos exposure (table 4). It has been stated that the underlying lung is invariably abnormal, ${ }^{20}$ but in the present series most cases run an uncomplicated course without signs of lung disease. Judging from table 4, mesotheliomas are a common late complication, or the exudate might be the first sign of the tumour. Three years of observation, as in the first two cases of table 3 , is a short period to exclude a mesothelioma, but the absence of symptoms or radiological signs is against this diagnosis. The cases in table $\mathbf{4}$ are probably heavily selected explaining the high incidence of tumour.

Pleural effusion caused by asbestos exposure is 


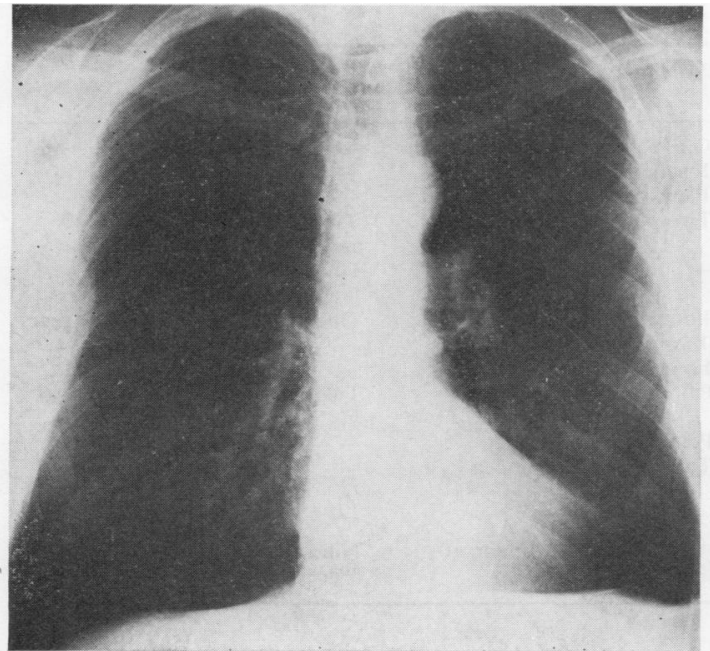

(a)

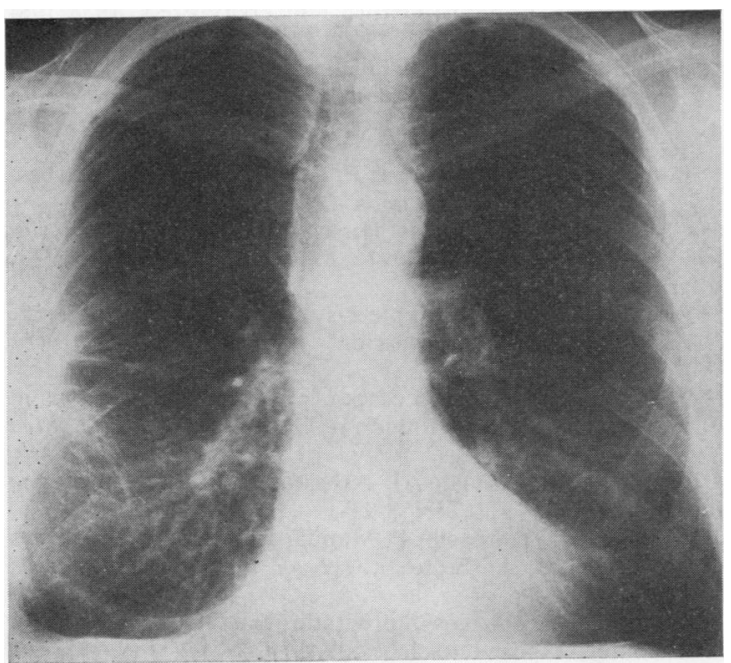

(c)

often asymptomatic. ${ }^{516}$ Of the 22 proven effusions in this series, all but one were discovered accidentally. Only 10 of them-that is, less than half-left radiologically visible remnants. Thus, those exudates that are diagnosed are only the top of the iceberg.

Apart from tuberculosis, collagen diseases, and drug-induced reactions, mesothelioma is the main differential diagnosis. Vigorous investigation to prove or disprove this diagnosis seems unwarranted in view of the disappointing results of treatment of this tumour.

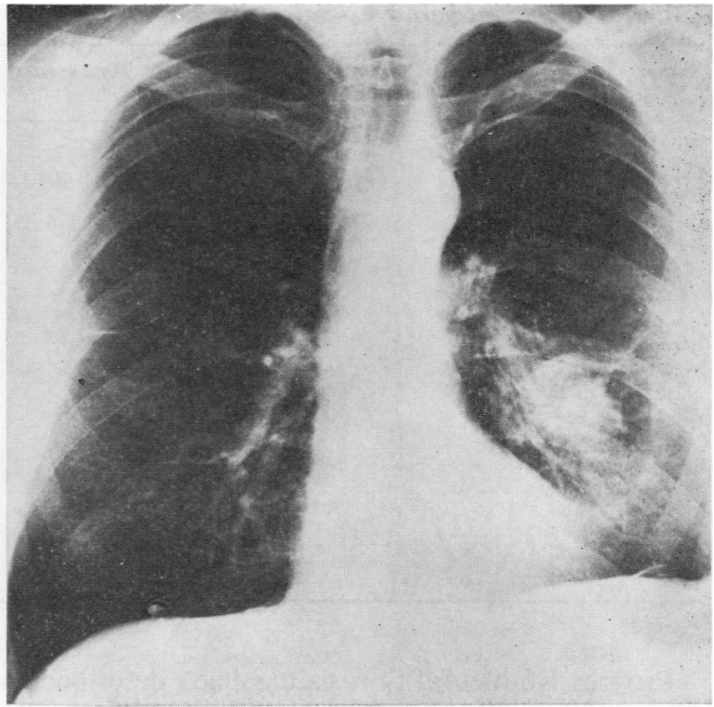

(b)

Fig 3 a: 1969. Rounded left sinus, pleural plaque laterally on right. $b$ : Same patient, 1973. Left, extensive pleural changes. Right, plaque has grown and interlobar fissure has thickened (type 3). c: Same patient, 1978. Pleurectomy on left side; on the right, rounded angle and pleural fibrosis with crows' feet.

Thickening of visceral pleura occurs in many patients exposed to asbestos and is easily demonstrated by the pathologist but difficult for the radiologist to see, except in the fissures. The pleura gradually thickens with time ${ }^{62122}$ and finally calcifies. ${ }^{23}$ Calcification can also be seen in the major fissures (Sargent EN, personal communication 1980). Thus, there is a striking parallel with the plaques in the parietal pleura, the main difference being that the visceral thickening is more diffuse and therefore more difficult to see on radiographs. 
Table 4 Benign asbestos exudates: literature review

\begin{tabular}{|c|c|c|c|c|c|}
\hline Author & $\begin{array}{l}\text { Number of } \\
\text { cases }\end{array}$ & $\begin{array}{l}\text { Latency } \\
\text { mean }\end{array}$ & $\begin{array}{l}\text { Time (years) } \\
\text { limits }\end{array}$ & Symptoms & Complications \\
\hline Boutin et $a l^{8}$ & 3 & 44 & $42-49$ & One pleuritic pain & - \\
\hline Chrétien et al ${ }^{9}$ & 10 & 26 & $10-38$ & Insidious & 一 \\
\hline Eisenstadt ${ }^{10}$ & 1 & - & - & Pleuritic pain & - \\
\hline Eisenstadt ${ }^{11}$ & 3 & 一 & 一 & Two pain, one also fever & $\begin{array}{l}\text { Two mesotheliomas (after } 10 \\
\text { and } 14 \text { yrs respectively) }\end{array}$ \\
\hline Elder $^{12}$ & 13 & - & - & - & $\begin{array}{l}\text { Four mesotheliomas and } 2 \\
\text { lung cancers after some years }\end{array}$ \\
\hline Gaensler and Kaplan ${ }^{13}$ & 12 & 20 & $4-46$ & Four pain, 9 dyspnoea & One mesothelioma after 12 years \\
\hline Léménager et $a^{14}$ & 5 & 22 & $7-46$ & Two pain and dyspnoea & - \\
\hline Mattson $^{15}$ & 11 & 18 & $6-29$ & Four slight pain & - \\
\hline Navrátil and Dobias ${ }^{16}$ & 7 & - & - & Pain in some cases & $\begin{array}{l}\text { Two mesotheliomas, } 4 \text { deaths } \\
\text { in "pleural hyalinosis" }\end{array}$ \\
\hline Nyiredy ${ }^{17}$ & 1 & 14 & - & Pain & - \\
\hline $\begin{array}{l}\text { Sluis-Cremer and } \\
\text { Webster }^{18}\end{array}$ & 9 & 14 & $6-36$ & Three pain, 2 dyspnoea & - \\
\hline Smyth 19 & 1 & 45 & - & - & - \\
\hline Total & 75 & 22 & $4-49$ & $\begin{array}{l}\text { Approximately } 20 \text { pain, } 10 \\
\text { dyspnoea }\end{array}$ & $\begin{array}{l}\text { Nine mesotheliomas, } 2 \text { cancers, } \\
4 \text { deaths of "pleural hyalinosis" }\end{array}$ \\
\hline
\end{tabular}

Progressive pleural fibrosis has been described by many authors. ${ }^{517} 2425$ Wright et al ${ }^{26}$ believed the patients' dyspnoea to be caused by restrictive pleural fibrosis compressing the lung, but fibrosis of the lung itself probably often coexists, making pleurectomy of doubtful value. Important differential diagnoses are drug reactions and mesothelioma. The prognosis of these lesions is variable. In some patients we now have a follow-up of a decade or more with only slight handicap and slow progression, while others rapidly develop severe dyspnoea.

"Atelectatic pseudotumours" may be caused by fibrotic changes in the pleura of any cause, leading to deformation of the underlying !ung and a bronchographic picture reminiscent of "trees bent by the wind". ${ }^{27-33}$ In asbestosis this has been described as "broom deformation".1628 If this deformation causes kinking of some bronchi, a "rounded atelectasis" can occur. The lung can also become atelectatic while floating in an effusion and by adhesions remain so when the exudate is absorbed. These pseudotumours are not uncommon in persons exposed to asbestos. ${ }^{30}$

\section{References}

${ }^{1}$ Becklake MR. State of the art: asbestos-related diseases of the lung and other organs: their epidemiology and implications for clinical practice. Am Rev Respir Dis 1976;114:187-227.

${ }^{2}$ Hillerdal G, Hillerdal O, Nöu E. Radiologically visible pleural plaques in a one-year material from a health survey in 1976. Europ J Respir Dis 1980;61: suppl. no $107: 89-98$.

${ }^{3}$ UICC/Cincinatti classification of the radiographic appearances of pneumoconioses. Chest 1970;58:57-67.

${ }^{4}$ Hillerdal G. Pleural plaques in a health survey material. Frequency, development and exposure to asbestos. Scand J Respir Dis 1978;59:257-63.
${ }^{5}$ Mackenzie FAF, Harries PG. Changing attitudes to the diagnosis of asbestos disease. $J$ Roy Nav Med Serv 1970;56:116-23.

${ }^{6}$ Gloyne SR. Pathology. In: Lanza EJ, ed. Silicosis and asbestosis. London: Oxford University Press, 1938:198256.

${ }^{7}$ Hillerdal G, Lindgren A. Pleural plaques: correlation of occurrence at autopsy to radiographic findings and occupational history. Europ J Respir Dis 1980;61:315-9. See page 007

8 Boutin C, Viallat J, Farisse P, Choux R. Pleurésies asbestosiques bénignes. Poumon Coeur 1975;31:111-8.

${ }^{9}$ Chrétien J, Chahinian P, Hirsch A, Nebut M. Pleurésies non tumorales de l'asbeste. Rev Franc Mal Respir 1976; 4:suppl2:87-92.

${ }^{10}$ Eisenstadt HB. Asbestos pleurisy. Dis Chest 1964;46:78-81

${ }^{11}$ Eisenstadt HB. In: discussion. Ann N Y Acad Sci 1965; 132:596-9.

12 Elder JL. A study of 16 cases of pleurisy with effusions in ex-miners from Wittenoom Gorge. Aust NZ J Med $1972 ; 2: 328-9$.

${ }^{13}$ Gaensler EA, Kaplan AI. Asbestos pleural effusion. Ann Intern Med $1971 ; 74: 178-91$.

${ }^{14}$ Léménager J, Rousselot P, Mandard JG et al. Les pléresies benignes de l'asbeste. Rev Franc Mal Respir 1974;4: suppl 2:75-86.

${ }_{15}$ Mattson SB. Monosymptomatic exudative pleurisy in persons exposed to asbestos dust. Scand J Respir Dis $1975 ; 56: 263-72$.

${ }^{16}$ Navrátil M, Dobias J. Development of pleural hyalinosis in long term studies of persons exposed to asbestos dust. Environ Res 1973;6:455-72.

17 Nyiredy G. Benigne asbestpleuritis. Prax Pneumol 1975; N 29:166-9.

18 Sluis-Cremer GK, Webster I. Acute pleurisy in asbestos exposed persons. Environ Res 1972;5:380-92.

${ }^{19}$ Smyth NPD, Goodman NG, Basu AP, Keshishian JM. Pulmonary asbestosis. Chest $1971 ; 60: 270-3$.

20 Preger L. Asbestos-related disease. New York: Grune and Stratton, 1978.

${ }^{21}$ Solomon A, Webster I. The visceral pleura in asbestosis Environ Res 1976;11:128-34.

${ }^{22}$ Solomon A, Irwig LM, Sluis-Cremer GK, Thomas RG, Du Toit RSJ. Thickening of pulmonary interlobar fissure: exposure-response relationship in crocidolite and amosite miners. Br J Ind Med 1977;36:195-8. 
${ }^{23}$ Solomon A, Sluis-Cremer GK, Goldstein B. Visceral pleural plaque formation in asbestosis. Environ Res 1979;19:258-64.

${ }^{24}$ Harries PG. Experience with asbestos disease and its control in Great Britain's naval dockyards. Environ Res $1976 ; 11: 261-7$.

${ }^{25}$ Baris YI, Sahin AA, Ozesmi M et al. An outbreak of pleural mesothelioma and chronic fibrosing pleurisy in the village of Karain/Urgup in Anatolia. Thorax 1978; 33:181-92.

${ }^{28}$ Wright PH, Hanson A, Kreel L, Capel LH. Respiratory function changes after asbestos pleurisy. Thorax 1980; 35:31-6.

27 Gernez-Rieux C, Mereau J. Deformations arciformes des bronches zonaires, séquelle méconnue de pléuresie ancienne. Ann Radiol (Paris) 1960;3:561-70.

28 Jacob G, Bohlig H. Das Verhalten des Bronchialbaumes bei der Asbestlungenfibrose. Arch Gewerbepath Gewerbehyg 1960;18:247-57.

29 Hanke, R. Rundatelektasen (Kugel- und Waltzenatelektasen). Ein Beitrag zur Differentialdiagnose intrapulmonaler Rundherde. Fortschr Röntgenstr 1971; 114:164-83.

${ }^{30}$ Bénard Y, Mandard JC, Evrard C, Léménager J. Opacité ronde pseudotumorale par atélectasie (á propos d'une observation). Rev Franc Mal Respir 1973;1:1171-7.

31 Blesovsky A. The folded lung. Br J Dis Chest 1966;60: 19-22.

${ }^{32}$ Choffel C, Verdoux P, Milleron B. Les atélectasies rondes pseudotumorales sans antécédents pleuraux avérés. Poumon Coeur 1977;33:295-302.

${ }^{33}$ Hillerdal G, Hemmingson A. Pseudotumor of the lung and asbestos. Acta \$Radiologica 1980; Acta Radiol (Diagn) 1980;21:615-20. 